\title{
Nutritional Responses of the Black Cutworm, Agrotis ipsilon (Hufn.), Larvae under Toxicity Effects of Five Wild Botanical Extracts from Sinai, Egypt
}

\author{
Enas E. Nasr ${ }^{1^{\star}}$, Samir S. Teleb ${ }^{2}$ and Amira I. Abou-Saty ${ }^{2}$ \\ ${ }^{1}$ Department of Zoology, Faculty of Science, Zagazig University, 44519 Zagazig, Egypt. \\ ${ }^{2}$ Botany Department, Faculty of Science, Zagazig University, 44519 Zagazig, Egypt.
}

Authors' contributions

This work was carried out in collaboration among all authors. Author EEN done the procedures on insects, statistical analysis, original draft, and reviewers' modifications to the manuscript. Authors SST

and AIAS administered and interpreted laboratory analyzes of the tested oils. All authors read and approved the final manuscript.

Article Information

DOI: $10.9734 / A R R B / 2021 / v 36 i 330351$

Editor(s):

(1) Dr. Rishee K. Kalaria, Navsari Agricultural University, India.

Reviewers:

(1) Naheed Akhter, Government College University, Pakistan

(2) Sarah Zaidan, University of Pancasila, Indonesia. Complete Peer review History: http://www.sdiarticle4.com/review-history/66558

Original Research Article

Received 14 January 2021

Accepted 21 March 2021

Published 07 April 2021

\section{ABSTRACT}

Aims: To identify the chemical components of five wild Botanical oils (BOs) and their larvicidal influences on the anti-nutritional indices of the $4^{\text {th }}$ instar larvae of Agrotis ipsilon.

Study Design: A comparative study with the randomized design, using five plant Extracts replicated five times.

Place and Duration of Study: Mentha Iongifolia, Artemisia judaica, Majorana hortensis, Origanum syriacum, and Achillea santolina were collected from the Sinai desert, Egypt. Study procedures were done at the Laboratory of Botany and Zoology, Faculty of Science, Zagazig University, Egypt, between December 2018 and June 2020.

Methodology: An analysis of the tested BOs components was done using a Shimadzu GC-9A gas chromatograph. Five sub-lethal concentrations of each plant were prepared (5 replicate/treatment) to evaluate medium lethality against $A$. ipsilon larvae (20 larvae/replicate). Untreated larvae were used distilled water only as a control. Ten larvae of each treatment were treated with only one $\mathrm{LC}_{50}$ to estimate the effect of different tested BOs on anti-nutritional Activities. 
Results: The main component of the M. Iongifolia and $A$. judaica oil was Piperitone at 39.79 and $37.55 \%$, respectively; whereas the $M$. hortensis, $O$. syriacum, and $A$. santolina oil was Terpinen-4ol, Thymol, and Fragranyl acetate at 29.82, 31.21, and $25.67 \%$, respectively. According to $L_{50}$ of the tested BOs, the toxicity of $A$. judaica, M. longifolia, O. syriacum, respectively, were the most effective oils, while $M$. hortensis and $A$. santolina oils were the least susceptibilities. The more toxic oils reduced food consumption, causing a significant decrease in relative consumption rate (RCR), growth rate (RGR), and efficiency of conversion of ingested food (ECl)/digested (ECD). The previous oils also showed a significant increase in metabolic cost (MC) and anti-feeding activities against $A$. ipsilon larvae compared to $M$. hortensis and $A$. santolina.

Conclusion: It is suggested that $A$. judaica and $M$. longifolia extracts contain high Piperitone content and could be accepted as toxicants to control $A$. ipsilon.

Keywords: Organic composition; wild plants; larvicidal; consumption; metabolism; growth rate; antifeedant; black cutworm.

\section{INTRODUCTION}

The black cutworm, Agrotis ipsilon (Hüfn.), (Lepidoptera: Noctuidae) is a common destructive phytophagous insect-pest. In Egypt, it causes severe damage not only; on cotton but also; to a large number of field and vegetable crops [1]. Moreover, A. ipsilon larvae are not a climbing cutworm, so most of their feeding occurs below or at the soil surface level. The early instar larvae only attack the epidermis of the leaves and stem of the young seedling at night, reducing crop yield and causing substantial economic losses [2]. They can feed on more than 400 square centimeters of crops during their growth, but more than $80 \%$ of the consumption records after beginning newly molted fourth instar larvae [3,4]. In previous years, the intensive use of chemical pesticides was led to undesirable impacts on non-target insects, wildlife, and insecticide-resistant strains [5], also hazardous to animals and humans by pesticide residues and environmental pollution [6]. Therefore, more attention is given to safer methods to control such pests as an optional alternative to conventional insecticides.

Essential oils as botanical extracts were considered one of these approaches that reduced the different problems of synthetic insecticides; because they contain a wideranging of bioactive chemicals, which are easy to use, non-dangerous, and qualitative in their work $[7,8]$. The Egyptian Deserts, especially the Sinai Peninsula, are distinguished by the abundance of wild plants that; are widely used in folk remedies for different diseases. These plants belong to more than fifty families, many of which are used as pesticides [9]. Desert plant-derived oils consist of a definitive group of volatile compounds that give a distinct flavor or odor to these plants. They also principally contain sesquiterpenes, monoterpenes, and their oxygenated derivatives as plant secondary metabolites [10]. Furthermore, they often include several types of molecules; most of them are natural mixtures of phenylpropanoids and turbines, which are helpful due to their biological activity $[11,12]$.

In this regard, the results of previous studies indicated that botanical extracts and their terpenes could be accepted as toxicants to control $A$. ipsilon. Jeyasankar [13] showed that gaultheria oil was more effective than eucalyptus oil on insecticidal activities against $A$. ipsilon larvae. Also, Elhosary et al. [14] achieved a noticeable decrease in some growth indices after treatment $4^{\text {th }}$ instar larvae of $A$. ipsilon with mango seed extracts and water fleabane leaves. Sharaby and Elnujiban [15] reported that the mixture of some essential oils and terpenes improved their toxicity toward $A$. ipsilon Larvae, resulting in larval deformation and growth inhibition. Elbadawy et al. [16] indicated that jojoba oil was most effective against the $4^{\text {th }}$ instar larvae of $A$. ipsilon, causing $60 \%$ mortality. Additionally, botanical extracts as antioxidants have been applied to many other lepidopterous insects such as Spodoptera littoralis [17], Spodoptera frugiperda [18].

Within the scope of previous studies, no study compared the activity of BOs for Mentha longifolia, Artemisia judaica, Majorana hortensis Moench., Origanum syriacum L. subsp. sinaicum, and Achillea santolina L. as toxicants against $A$. ipsilon. So the present study aimed to identify the chemical components of the tested BOs and their larvicidal influences on the antinutritional indices of the $4^{\text {th }}$ instar larvae of $A$. ipsilon. 


\section{MATERIALS AND METHODS}

\subsection{Insects and Rearing Technique}

Newly moulted $4^{\text {th }}$ instar larvae of the $A$. ipsilon were provided from a laboratory culture at the Plant Protection Research Institute, Giza, Egypt. Castor bean leaves (Ricinus communis L.) were used as larval diets under laboratory conditions at $25 \pm 2^{\circ} \mathrm{C}, 60-70 \% \mathrm{RH}$, and $12 \mathrm{~h}$ light per day. The larvae were reared individually in clear plastic cups ( $7 \mathrm{~cm}$ deep by $5 \mathrm{~cm}$ diameter) to prevent larval cannibalism habits. In each treatment, fresh castor leaves were cleaned daily with sterile water and dried before treated with tested BOs or eaten by untreated larvae. The rearing technique was applied along the following larval stages until pupation happened. The newly formed pupae were kept inside glass jars until the moth's emergence, where female and male moths (1:1) were moved into a glass jar (2L) which was provided with a suspended piece of cotton soaked with a $15 \%$ sucrose solution (2 days/period). Strips cloth set in the muslin cap were applied as hanging places for egg deposition, which daily collected.

\subsection{Plant Materials and BOs Isolation Process}

Wild plants were collected from various places of the south Sinai desert, Egypt. Characterization and site localization of the tested plants are shown in Table 1. Plant material was distinguished at the Laboratory of Botany Department, Faculty of Science, Zagazig University, Egypt.

The plant materials were air-dehydrated at $23 \pm 3^{\circ} \mathrm{C}$ with suitable ventilation for $10-14$ days until they became brittle and then milled into a fine powder form. The air-dehydrated sample was subjected to hydro-distillation using a Clevenger type apparatus for $4 \mathrm{hrs}$. (250g sample/1000ml distilled water), according to Louni et al. [19]. Anhydrous sodium sulphate was used to extract oil-free water and saved in a fridge at; $5^{\circ} \mathrm{C}$ until needed. The BOs content was estimated as a relative percentage $(\mathrm{v} / \mathrm{w})$. The used parts for extraction, physical properties, and yield ratios of the BOs derived from current plant species are shown in Table 2.

\subsection{Identification of BOs Compounds Using (GC-MS) Analysis}

An analysis of the tested BOs components was performed using a Shimadzu GC-9A gas chromatograph attached to the mass spectrometer detector. The GC-MS analysis was carried out on a Varian 3400 system equipped with a DB-5 fused silica column (30m length $x$ $0.25 \mathrm{~mm}$ diameter, $0.25 \mu \mathrm{m}$ film thickness). The oven temperature was initially installed for 5 minutes at $40^{\circ} \mathrm{C}$ and then programmed to increase the temperature of $4^{\circ} \mathrm{C}$ per minute until $250^{\circ} \mathrm{C}$. The detector and injector temperature was $260^{\circ} \mathrm{C}$. Helium was used as a carrier gas using $31.5 \mathrm{~cm} / \mathrm{sec}$ linear velocity, $1.1 \mathrm{~mL} / \mathrm{min}$ flow rate, and 1/60 split ratio, $70 \mathrm{eV}$ ionization energy for $1 \mathrm{sec}$ scan time, 40-350 amu mass range. The elements of the tried $\mathrm{BOs}$ were recognized by correlation of their Kovat's records and mass-spectra designs with those accessible in the library data set (NIST, WILEY). Kovat's indices were specified by co-injection of the samples with a solution, including a homologous sequence of $n$-alkanes (C8-C22) under the same conditions described by Adams [20]. The relative concentration of each constituent of the BOs was computed by the analysis program based on the peak area integrated without using correction factors.

\subsection{Toxicity of the Tested BOs against $A$. ipsilon Larvae}

Newly molted $4^{\text {th }}$ instar larvae of $A$. ipsilon were the most susceptible stage to some of the botanical extracts, according to ELhosary et al. [14] and El-Badawy et al. [16]. Five concentrations; of each BO were prepared (125,

Table 1. Species list of the tested wild plants and their site localization

\begin{tabular}{llllll}
\hline Scientific name & Family & \multicolumn{2}{c}{ English name Site (Wadi) } & \multicolumn{2}{c}{ GPS location } \\
\cline { 5 - 6 } & & & & Latitude N & Longitude E \\
\hline Mentha longifolia & Lamiaceae & Horse mint & El-Raha & $28^{\circ} 34^{\prime} 07.2^{\prime \prime}$ & $33^{\circ} 57^{\prime} 28.2^{\prime \prime}$ \\
Artemisia judaica & Asteraceae & Wormwood & Al-Arbaeen & $28^{\circ} 32^{\prime} 30.2^{\prime \prime}$ & $33^{\circ} 57^{\prime} 34.3^{\prime \prime}$ \\
Majorana hortensis & Lamiaceae & Marjoram & Um Adawi & $28^{\circ} 05^{\prime} 13.8^{\prime \prime}$ & $34^{\circ} 22^{\prime} 46.0^{\prime \prime}$ \\
Origanum syriacum & Lamiaceae & Oregano & El-Deir & $28^{\circ} 33^{\prime} 25.2^{\prime \prime}$ & $33^{\circ} 58^{\prime} 32.6^{\prime \prime}$ \\
Achillea santolina & Asteraceae & milfoil & El-Raha & $28^{\circ} 33^{\prime} 52.8^{\prime \prime}$ & $33^{\circ} 57^{\prime} 34.4^{\prime \prime}$ \\
\hline
\end{tabular}


Table 2. Physical Properties and yield ratios of the tested BOs derived from five plant species

\begin{tabular}{|c|c|c|c|c|c|}
\hline \multirow[t]{2}{*}{ Plants } & \multirow[t]{2}{*}{ Part used } & \multicolumn{3}{|c|}{ Physical Characteristic } & \multirow[t]{2}{*}{ Oil yield (\%) } \\
\hline & & Odor & Color & Density(g/mL) & \\
\hline M. longifolia & Leaves & Minty & Pale yellow & 0.795 & 0.59 \\
\hline A. judaica & Aerial parts & Herbal & Light yellow & 0.912 & 0.88 \\
\hline M. hortensis & Leaves & spicy herbal & Light yellow & 0.871 & 1.37 \\
\hline O. syriacum & Aerial parts & Minty & Colorless & 0.931 & 0.71 \\
\hline A. santolina & Aerial parts & Fragrant & yellowish green & 0.845 & 0.46 \\
\hline
\end{tabular}

250, 500, 1000, and 2000 ppm). Castor leaves were dipped in each concentration level; of each BO for 15 seconds and air-dried on filter papers at room temperature. Equal discs of treated leaves ( $3 \mathrm{~cm}$ in diameter) were supplied for $48 \mathrm{~h}$ to newly molted $4^{\text {th }}$ instar larvae and then replaced daily by another fresh one until pupation. The previous step was repeated using distilled water only as control. Larvae were starved for four $h$ before being transferred individually into plastic cups. The tested BOs were distributed into five groups of cups, each of which was divided into five subgroups to be treated with one of the previously prepared concentrations. Each concentration was replicated five times (20 larvae/replicate). Another group was identified without any treatments as control [21]. The mortalities were checked daily and corrected by Abbott's formula [22].

\subsection{Anti-nutritional Activities of the Tested BOs against $A$. ipsilon Larvae}

Ten larvae of each treatment were treated with only one LC50 value to evaluate the effect of different tested BOs on anti-nutritional Activities. Each treatment was replicated five times. Each cup of the control sample was supplied by known weighed disks of fresh castor leaves, treated with the sub-lethal concentration of each treatment, according to Shaurub et al. [23]. All the larvae, food supplied, food unconsumed, and larvae feces were weighed daily before and after feeding until the pupation was done. All above weights were expressed as dry weight percentages using an oven at $60^{\circ} \mathrm{C}$ for $48 \mathrm{~h}$. Fresh and dry weights of these components were registered daily to evaluate the feeding indices. The methodology recommended by Truzi et al. [24], based on Scriber and Slansky [25], was used to estimate the quantitative nutritional parameters of the $4^{\text {th }}$ instar larvae of $A$. ipsilon as follows: the weight of feces produced $(F)$, food ingested $(I)=F+A$, food assimilated $(A)=I-F$, food metabolized $(M)=(I-F)-B$, weight gain by larvae $(B)=(I-F)-M$, duration of feeding period
(T), mean weight of larvae during feeding period (L), relative consumption $(R C R)=I /\left(L^{*} T\right)$, metabolic $(R M R)=M /\left(L^{*} T\right)$, and growth rates $(R G R)=B /\left(L^{*} T\right)$, the efficiency of conversion of ingested food $(E C l)=(B / I)^{*} 100$, the efficiency of conversion of digested food $(E C D)=(B / I-F) * 100$, approximate digestibility $(A D)=((I-F) / I)^{*} 100$, metabolic cost $(\mathrm{MC})=100-\mathrm{ECD}$, anti-feeding Activity $=[(\text { I control-treated }) / / \text { control }]^{*} 100$.

\subsection{Statistical Analysis}

The lethality values were evaluated based on probit analysis [26]. To determine the LC50 values, Fiducial limits (95\%) of each treatment, and slope, under IBM-SPSS software version 25.00, significant differences among the treatments were analyzed using one-way ANOVA. Means were significantly ordered by using Fisher's LSD test at 0.05 levels [27].

\section{RESULTS AND DISCUSSION}

\subsection{Chemical Constituents of Tested BOs Derived from Wild Plants}

The chemical composition was analyzed of the tested $\mathrm{BOs}$ of $M$. longifolia, $A$. judaica, $M$. hortensis, $O$. syriacum, and $A$. santolina. The principal ingredients of each oil and Kovats index were also; organized in Table 3 . The qualitative composition results showed the main components of the $M$. longifolia oil were Piperitone, 1,8-Cineole, Pulegone, Limonene, Lmenthone, Caryophyllene, germacrene-D, and Terpinen-4-ol 39.79, 9.85, 7.12, 5.76, 4.95, 4.81, 3.79 , and $3.01 \%$, respectively. Besides, the principal components of $A$. judaica oil were Piperitone, Camphor, E-ethyl cinnamate, Terpinen-4-ol, and Spathulenol 37.55, 21.19, $15.34,5.75$, and $4.08 \%$, respectively. The main components of the $M$. hortensis oil were Terpinen-4-ol, $\mathrm{Y}$-Terpinene, E-sabinene hydrate, and $\alpha$-Terpinene was recorded 29.82, 15.15, 11.35 , and $9.71 \%$, respectively. Additionally, 0 . syriacum oil scored $(31.21,15.37,12.07,9.64$, 
$6.03,5.96,4.73$, and $4.11 \%$, respectively) for Thymol, $y$-Terpinene, Terpinen-4-ol, Carvacrol, trans- $\beta$-ocimene, $\alpha$-Terpinene, $p$-Cymene, and Sabinene. Finally, the prime components of $A$. santolina oil were Fragranyl acetate, 1,6-

Dimethyl-1,5-cyclooctadiene, Fragranol, $\beta$ Thujone, and 1,8-Cineole at 25.67, 16.71, 10.27, 8.39 , and $7.26 \%$, respectively.

Table 3. Chemical components of the BOs were extracted from the tested plants by hydrodistillation using analyzed by GC-MS

\begin{tabular}{|c|c|c|c|c|c|c|c|}
\hline \multirow[t]{2}{*}{ Components } & \multirow{2}{*}{\multicolumn{2}{|c|}{$\begin{array}{l}\text { mol wt. KI } \\
\text { (g/mol) }\end{array}$}} & \multicolumn{5}{|c|}{ Composition (\%) } \\
\hline & & & $\begin{array}{l}\text { M. } \\
\text { longifolia }\end{array}$ & $\begin{array}{l}\text { A. } \\
\text { judaica }\end{array}$ & $\begin{array}{l}\text { M. } \\
\text { hortensis }\end{array}$ & $\begin{array}{l}\text { O. } \\
\text { syriacum }\end{array}$ & $\begin{array}{l}\text { A. } \\
\text { santolina }\end{array}$ \\
\hline$\alpha$-Thujene & 136 & 931 & 0.19 & - & 0.97 & 1.36 & - \\
\hline$\alpha$-Pinene & 136 & 939 & 1.93 & 0.35 & - & 0.91 & 0.49 \\
\hline Camphene & 136 & 953 & 0.32 & 0.47 & - & - & 0.75 \\
\hline Sabinene & 136 & 976 & 1.54 & 0.91 & 2.99 & 4.11 & 0.45 \\
\hline$\beta$-Pinene & 136 & 980 & 0.85 & 0.39 & - & - & 0.13 \\
\hline Myrcene & 136 & 991 & 0.97 & 0.76 & 1.31 & 2.05 & - \\
\hline$\alpha$-Phellandrene & 136 & 1005 & - & 2.63 & 0.95 & & - \\
\hline$\alpha$-Terpinene & 136 & 1018 & - & 0.45 & 9.71 & 5.96 & 1.02 \\
\hline p-Cymene & 134 & 1026 & 0.31 & - & 3.15 & 4.73 & 2.15 \\
\hline Limonene & 136 & 1031 & 5.76 & - & - & - & - \\
\hline 1,8-Cineole & 154 & 1033 & 9.85 & 0.72 & - & - & 7.26 \\
\hline trans- $\beta$-ocimene & 136 & 1050 & - & - & - & 6.03 & - \\
\hline $\mathrm{Y}$-Terpinene & 136 & 1062 & 0.87 & - & 15.15 & 15.37 & 0.91 \\
\hline Terpinolene & 136 & 1088 & - & - & 3.62 & 1.56 & 0.18 \\
\hline Linalool & 154 & 1098 & 1.33 & - & - & - & 0.40 \\
\hline (E)-sabinene hydrate & 154 & 1115 & - & - & 11.35 & - & 1.31 \\
\hline$\beta$-Thujone & 152 & 1143 & - & - & - & - & 8.39 \\
\hline Camphor & 152 & 1145 & - & 21.19 & - & - & 5.17 \\
\hline L-menthone & 154 & 1154 & 4.95 & - & - & - & - \\
\hline Isoborneol & 154 & 1156 & 2.62 & 0.64 & - & - & 3.85 \\
\hline Terpinen-4-ol & 154 & 1177 & 3.01 & 5.75 & 29.82 & 12.07 & 5.11 \\
\hline$\alpha$-Terpineol & 154 & 1189 & 1.98 & 0.98 & 2.03 & 0.42 & 3.05 \\
\hline Fragranol & 154 & 1196 & - & - & - & - & 10.27 \\
\hline Verbenone & 150 & 1204 & - & 0.77 & - & - & - \\
\hline Pulegone & 152 & 1237 & 7.12 & - & - & - & - \\
\hline Geranial & 152 & 1270 & - & 1.36 & 0.18 & - & - \\
\hline piperitone & 152 & 1282 & 39.79 & 37.55 & 0.37 & - & 0.35 \\
\hline Thymol & 150 & 1290 & - & - & 0.25 & 31.21 & 0.58 \\
\hline Carvacrol & 150 & 1298 & - & 0.55 & - & 9.64 & 0.31 \\
\hline Fragranyl acetate & 196 & 1335 & - & - & - & - & 25.67 \\
\hline a-Cubebene & 204 & 1351 & 0.54 & - & - & - & - \\
\hline a-Humulene & 204 & 1451 & 0.85 & - & 0.43 & 0.10 & - \\
\hline caryophyllene & 204 & 1454 & 4.81 & 1.88 & 3.61 & 0.75 & 0.25 \\
\hline$\beta$-Farnesene & 204 & 1458 & 0.34 & 0.47 & - & - & - \\
\hline (E)-ethyl cinnamate & 176 & 1460 & - & 15.34 & - & - & - \\
\hline y-Muurolene & 204 & 1477 & - & - & - & - & - \\
\hline germacrene-D & 204 & 1480 & 3.79 & - & 0.95 & - & 0.70 \\
\hline$\beta$-Selinene & 204 & 1485 & - & - & - & - & - \\
\hline Bicyclogermacrene & 204 & 1494 & - & - & 0.09 & 0.47 & 0.67 \\
\hline $\begin{array}{l}\text { 1,6-Dimethyl-1,5- } \\
\text { cyclooctadiene }\end{array}$ & 136 & 1503 & - & - & - & - & 16.71 \\
\hline y-Cadinene & 204 & 1513 & - & - & - & - & - \\
\hline$\delta$-Cadinene & 204 & 1524 & - & - & - & - & - \\
\hline cis-Nerolidol & 222 & 1534 & - & - & 0.11 & - & - \\
\hline spathulenol & 220 & 1575 & 0.59 & 4.08 & 1.89 & ND & 0.34 \\
\hline caryophyllene oxide & 220 & 1581 & - & - & - & - & 0.49 \\
\hline
\end{tabular}




\begin{tabular}{|c|c|c|c|c|c|c|c|}
\hline \multirow[t]{2}{*}{ Components } & \multirow{2}{*}{\multicolumn{2}{|c|}{$\begin{array}{l}\text { mol wt. KI } \\
\text { (g/mol) }\end{array}$}} & \multicolumn{5}{|c|}{ Composition (\%) } \\
\hline & & & $\begin{array}{l}\text { M. } \\
\text { longifolia }\end{array}$ & $\begin{array}{l}\text { A. } \\
\text { judaica }\end{array}$ & $\begin{array}{l}\text { M. } \\
\text { hortensis }\end{array}$ & $\begin{array}{l}\text { O. } \\
\text { syriacum }\end{array}$ & $\begin{array}{l}\text { A. } \\
\text { santolina }\end{array}$ \\
\hline 1-epi-cubenol & 222 & 1613 & - & 0.95 & - & - & - \\
\hline Tau-Cadinol & 222 & 1630 & 1.93 & 0.53 & 0.08 & 0.15 & - \\
\hline Torreyol & 222 & 1645 & - & - & - & - & - \\
\hline$\beta$-Eudesmol & 222 & 1649 & - & - & - & - & 0.22 \\
\hline a-Cadinol & 222 & 1653 & 0.41 & - & 0.31 & - & - \\
\hline Shyobunol & 222 & 1689 & - & - & - & - & - \\
\hline Unidentified & -- & -- & 3.35 & 1.28 & 10.68 & 3.11 & 2.82 \\
\hline
\end{tabular}

The main ingredients in Table 3 were observed in more than one plant, such as $\alpha$-Terpinene, $p$ Cymene, 1,8-Cineole, $\mathrm{Y}$-Terpinene, Camphor, Terpinen-4-ol, and piperitone, but others were special to the plant species. The main components of the oils were divided into four basic categories: monoterpene hydrocarbons ( $\alpha-$ Pinene, Camphene, Sabinene, $\beta$-Pinene, Myrcene, $\alpha$-Phellandrene, $\alpha$-Terpinene, $p$ Cymene, Limonene, trans- $\beta$-ocimene, $\quad \mathrm{-}$ Terpinene, Terpinolene, 1,6-Dimethyl-1,5cyclooctadiene), oxygenated monoterpenes (1,8Cineole, Linalool, (E)-sabinene hydrate, $\beta$ Thujone, Camphor, L-menthone, Isoborneol, Terpinen-4-ol, $\quad \alpha$-Terpineol, Fragranol, Verbenone, Pulegone, Geranial, piperitone, Thymol, Carvacrol, Fragranyl acetate, and (E)ethyl cinnamate), sesquiterpene hydrocarbons ( $\alpha$-Cubebene, $\alpha$-Humulene, caryophyllene, $\beta$ Farnesene, $\gamma$-Muurolene, germacrene-D, $\beta$ Selinene, Bicyclogermacrene, $\mathrm{Y}$-Cadinene, and $\bar{\delta}-$ Cadinene) and oxygenated sesquiterpenes (cisNerolidol, spathulenol, caryophyllene oxide, 1epi-cubenol, Tau-Cadinol, Torreyol, $\beta$-Eudesmol, a-Cadinol, and Shyobunol).

The different chemical categories of the identified compounds are already in Table 4. The identified components ratio scored 96.65, 98.72, 89.32,
96.89 , and $97.18 \%$, respectively, of the total composition oils. Oxygenated monoterpenes were the most abundant constituents, recording $70.65,84.85,44.00,53.34$, and $71.72 \%$, respectively, of the BOs. Moreover, monoterpene hydrocarbons recorded the second order with 12.74, 5.96, 37.85, 42.08, and 22.79\%, respectively. In contrast, the sesquiterpene hydrocarbons and oxygenated sesquiterpene were secondary components.

Essential oils as natural mixtures contained many components at different concentrations. A few of these composites are identified by high concentrations related to other compounds when analyzing these oils. In general, the majority of these BOs oils are terpenoids and terpenes with diverse functions [28]. There is a real variability in the chemical constitution of tested BOs collected from Egyptian plants if compared with the same species from other areas, depending on many differences including climate, geology, season, used part, vegetative cycle, geographical location, and the used method to extract the BO [29]. The main compounds obtained from an analysis of the BOs are similar to those of Salama et al. [30] stated that Piperitenone, Cispipertone, and limonene were classified as the most valuable chemical

Table 4. The BO components were derived from the tested plants with constituent categories

\begin{tabular}{|c|c|c|c|c|c|}
\hline \multirow[t]{2}{*}{ Components } & \multicolumn{5}{|c|}{ Composition (\%) } \\
\hline & $\begin{array}{l}\text { M. } \\
\text { longifolia }\end{array}$ & A. judaica & $\begin{array}{l}\text { M. } \\
\text { hortensis }\end{array}$ & $\begin{array}{l}\text { O. } \\
\text { syriacum }\end{array}$ & A. santolina \\
\hline Monoterpene hydrocarbons & 12.74 & 5.96 & 37.85 & 42.08 & 22.79 \\
\hline Oxygenated monoterpenes & 70.65 & 84.85 & 44.00 & 53.34 & 71.72 \\
\hline Total Monoterpenes & 83.39 & 90.81 & 81.85 & 95.42 & 94.51 \\
\hline Sesquiterpene hydrocarbons & 10.33 & 2.35 & 5.08 & 1.32 & 1.62 \\
\hline Oxygenated sesquiterpenes & 2.93 & 5.56 & 2.39 & 0.15 & 1.05 \\
\hline Total Sesquiterpenes & 13.26 & 7.91 & 7.47 & 1.47 & 2.67 \\
\hline Number of identified components & 25.00 & 22.00 & 22.00 & 17.00 & 28.00 \\
\hline identified components ratio & 96.65 & 98.72 & 89.32 & 96.89 & 97.18 \\
\hline
\end{tabular}


constituents in M. longifolia oil from Egypt. The results are also in agreement with previous studies from other countries that have recorded Piperitone and Limonene as the significant components of the $M$. longifolia oil [31,32], Piperitone component [33], and Menthon and Piperiton components [34]. However, the classification of monoterpene piperitone as the principal compound in M. longifolia oil contrasts sharply with the other findings as the oil contained carvone or ciscarveol $[35,36]$ as the main ingredient.

The previous investigations on the compound constituents of $A$. judaica oil gathered from the Sinai have concurred with the current results. Where; it was deep in piperitone $(27-46 \%)$, camphor (16-23\%), transethyl cinnamate (8$13 \%)$, and ethyl cinnamate (5-6\%) [37]. Conversely, chrysanthenol and camphor concentrations were presented in low amounts ( 0.14 and $0.38 \%$, respectively). Also, Abdelgaleil et al. [38] proved that the Egyptian A. judaica oil contained piperitone followed by trans-ethyl cinnamate; as the major constituents of the oil. Moreover, the main ingredients of $A$. Judaica oil were Piperitone, trans-ethyl cinamate, and ethyl3-phnyl propionate [39]. The principal components of oils studied by Abu-Darwish et al. [40] in Jordan were Piperitone, camphor ethyl cinnamate, comparable to those detected in the same plant in Egypt.

In M. hortensis oil, Twenty-two components were distinguished, addressing $89.32 \%$ of the oil. The significant constituents of this oil, Terpinen-4-ol, $y$-Terpinene, (E)-sabinene hydrate, and $\alpha$ Terpinene, were similar to that described by other authors [41,29]; however, the concentrations of the significant components produced from the oil could change possibly due to both genetic differences and environmental factors [42]. In the $O$. syriacum oil, seventeen compositions were identified, expressing $96.89 \%$ of the total components, the main ingredients being thymol, $\quad y$-terpinene, Terpinen-4-ol, Carvacrol, and trans- $\beta$-ocimene. Hence, this structure is similar to the $O$. syriacum oil grown in Egypt, in which thymol and $\mathrm{y}$-terpinene were the principal constituents [29]. In contrast, many studies have publicized that carvacrol and thymol were the two main components of $O$. Syriacum oil $[43,44]$.

The chemical profile of the Egyptian A. santolina displayed that oil contained Twenty-eight components, corresponding to $97.18 \%$ of the total composition. The essential oils derived from $A$. santolina in the current study coincided with the previous reports $[45,46]$. On the other hand, differences were observed in the fundamental parts of the oils of Achillea species like $A$. millefolium [47], A. biebersteinii $[48,46]$, and $A$. fragrantissima [45] compared to $A$. santolina. Furthermore, quite differences were showed between the same plant extract main components; in different countries of origin: Iran [49] and Algeria [50].

\subsection{Toxicity of the Tested BOs Against $A$. ipsilon Larvae}

The results in Fig. 1 indicated the mortality rate of $A$. ipsilon larvae under various concentrations of the examined BOs. The outcomes introduced that the most noteworthy mortalities were related to the highest BOs concentrations at $2000 \mathrm{ppm}$. They recorded $82,75,67,48$, and $40 \%$ mortalities for $A$. judaica, $M$. longifolia, $O$. syriacum, $M$. hortensis, and $A$. santolina, respectively. The low mortality percentages were

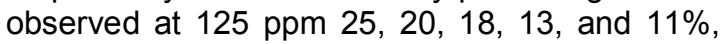
respectively, at above mention tested BOs. The data likewise reported that the most elevated cumulative increase in larval mortality was 25 , $33,49,71$, and $82 \%$, respectively, according to increasing the concentrations of $A$. judaica oil except; at 250 and 500 ppm concentrations. While the least cumulative increase in mortality was $(11,19,21,42$, and $40 \%$, respectively); when treated with various concentrations of $A$. santolina oil. Furthermore, this figure showed that $M$. longifolia oil had a higher larval mortality than in $O$. syriacum oil and then $M$. hortensis oil when treated with previous concentrations. The achieved results confirmed that $A$. judaica oil had higher mortalities and more successful than other tested BOs. On the contrary, A. santolina was the lowest one.

These results are similar to studies conducted on other plant extracts to control the same insect; Elbadawy et al. [16] exhibited that the mortalities were compatible with the increasing concentrations and exposure time. At the highest concentration, the mortality percentage was (3.33 - 30\%) after $48 \mathrm{~h}$ and increased to (33.3 $46.6 \%)$ for seven days after treated the larvae with the tested plant oils. Moreover, ELhosary et al. [14] declared that the larval mortalities differed under- tested plant extracts. The highest mortality rates were 66.6 and $80 \%$ when the larvae were uncovered to water flea and water 


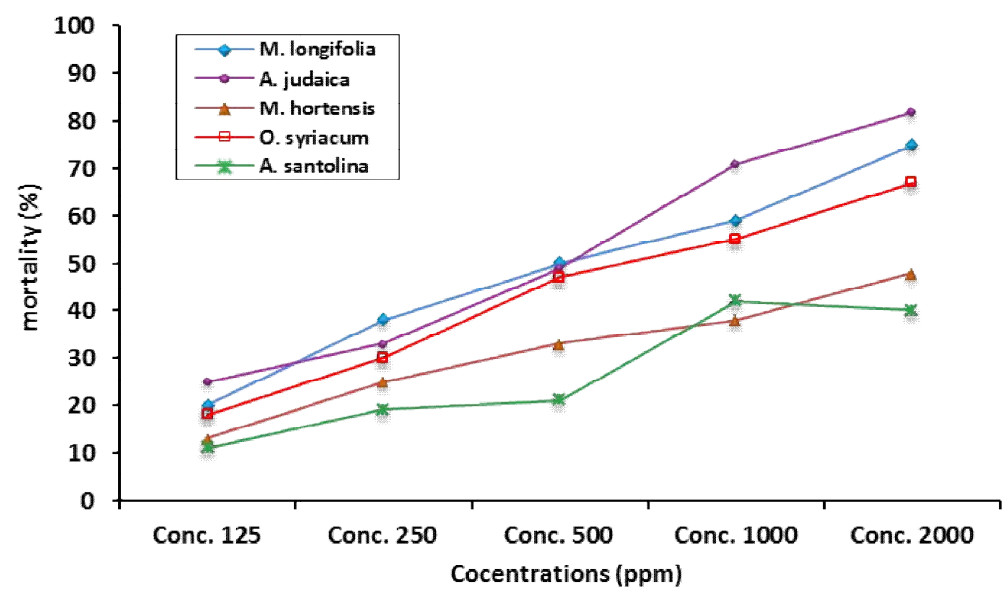

Fig. 1. Larval mortality of $A$. ipsilon under various concentrations of the tested BOs

mango extracts, respectively. The previous reports of other insects are consistent with the mortality rate after using one or more of the current plant extracts, as Al-Sharook et al. [51] stated that the mortalities of treated insects induced by plant oils, causing their failure to consume enough amounts of air to separate the used cuticle by a new one at ecdysis. Also, plant oils may increase a metamorphosis inhibiting according to the hormonal regulation disturbance. Also, Louni et al. [19] indicated that the mortalities of Ephestia kuehniella larvae were $84 \%$ on the $1^{\text {st }}$ day when treated with M. Iongifolia oil at $40000 \mathrm{ppm}$. The highest mortality up to 16 days of the $S$. littoralis larvae exposed to $A$. judaica mixed with Chromafenozide was 70 and $77 \%$ at 72 and 96 hrs, respectively [17].

The recorded data in Table 5 reviewed that the $\mathrm{LC}_{50 \text { s }}$ of the tested BOs against the $4^{\text {th }}$ instars were $600.70,486.33,1883.2,744.45$, and $1970.2 \mathrm{ppm}$, respectively. The current outcomes revealed that the toxicity of $A$. judaica oil was the best one compared to other BOs; meanwhile, M. longifolia oil was less toxic than A. judaica oil, followed by $O$. syriacum and $M$. hortensis oil. The $\mathrm{LC}_{50}$ value of $A$. santolina oil has less susceptibility against A. ipsilon larvae. Thus, there were differences among the toxicity indices of the tested BOs according to their $\mathrm{LC}_{50}$ values.

According to the current lethality values results, A. Judaica oil was more active as an insecticide. Meanwhile, $A$. santolina oil had less insecticidal activities against the $4^{\text {th }}$ instars. These results are partially similar to El-Sabrout et al. [52] when using $A$. Judaica oil for controlling $S$. littoralis larvae, containing monoterpenes Limonene, 1,8-
Cineole, $\alpha$-Phellandrene, and Camphor at most elevated concentrations in the total composition. Formulation of the $A$. judaica oil comprised a majority share of piperitone and Camphor, which gave the most effective oil in the insecticidal activity. In the same trend, Piperitone and transethyl cinnamate are considered to be the principal components of $A$. Judaica oil, which played an active role in the control of $S$. littoralis [38]. These results are similar to El-Massry et al. [39], who proved that Piperitone, ethyl cinnamate, and spathulenol are the chief components of the A. judaica oil.

The Chemical analysis of $M$. Iongifolia oil specified that the foremost compound was piperitenone oxide, which could be responsible for the higher efficiency of larvicidal activity. This compound belongs to the group of epoxyketone monoterpene [53]. Due to the lack of previous studies in controlling the lepidopteran insects using the M. longifolia extracts, Many studies of other insects have been shown a higher efficacy of piperitenone from Mentha species on these insects compared to other tested essential oils, such as M. spicata against Anopheles stephensi [54], M. microphylla against Tribolium castaneum and Sitophilus oryzae [55], M. spicata, M. suaveolens, and M. Iongifolia against Culex pipiens [56], and different Mentha L. Species against Culex quinquefasciatus [33].

Although some essential oils act as neurotoxic agents, the mechanism of the insecticide activity of $M$. hortensis oil is unclear [57]. Previous studies showed an increase in the toxicity activities of this oil compared to some of the main components isolated from it, particularly cterpinene and terpinen-4-ol against the $4^{\text {th }}$ instar 
Table 5. Lethality values and toxicity indices of the tried BOs against $A$. ipsilon $4^{\text {th }}$ instars

\begin{tabular}{|c|c|c|c|c|c|c|}
\hline \multirow[t]{2}{*}{ Treatments } & \multicolumn{5}{|c|}{$\begin{array}{ll}\text { Lethality variables } \\
\end{array}$} & \multirow{2}{*}{$\begin{array}{l}\text { Toxicity } \\
\text { index }\end{array}$} \\
\hline & $\begin{array}{l}\text { LC50 } \\
\text { (ppm) }\end{array}$ & $\begin{array}{l}\mathbf{9 5 \%} \\
\text { Fiducial limits } \\
\text { (Lower - Upper) }\end{array}$ & $\begin{array}{l}\text { Regression } \\
\text { equation } \\
(y=a \cdot x+b)\end{array}$ & $\mathbf{R}^{2}$ & Slope \pm SE & \\
\hline M. Iongifolia & 600.70 & $(281.00-1284.13)$ & $Y=1.23 x+1.58$ & 0.956 & $1.23 \pm 0.16$ & 81.0 \\
\hline A. judaica & 486.33 & $(250.94-942.50)$ & $Y=1.41 x+1.19$ & 0.969 & $1.41 \pm 0.14$ & 100 \\
\hline M. hortensis & 1883.2 & $(687.00-5162.65)$ & $Y=0.98 x+1.76$ & 0.898 & $0.98 \pm 0.22$ & 25.8 \\
\hline O. syriacum & 744.45 & $(350.57-1580.91)$ & $Y=1.26 x+1.38$ & 0.977 & $1.26 \pm 0.16$ & 65.3 \\
\hline A. santolina & 1970.2 & $(801.91-4840.49)$ & $Y=1.16 x+1.15$ & 0.919 & $1.16 \pm 0.19$ & 24.7 \\
\hline
\end{tabular}

larvae of $S$. littoralis and adults of Aphis fabae with $L_{50}$ values of $2.48 \mu \mathrm{g}$ and $1.86 \mathrm{~g} / \mathrm{l}$ in the topical application and rapid dipping assays, respectively [41]. Moreover, the insecticide activities of some essential oils against other order insects, including three of them in the present study, were evaluated against adult insects of $S$. oryzae and $T$. castaneum. According to $L C_{50}$ values of these oils, the $M$. hortensis was less toxic than A. Judaica oil in the insecticidal potential against both insects; however, it was more effective than $A$. santolina oil against these insects [55]. These results are similar to the toxic activity of some tested oils in the present study.

Although no previous study of the insecticidal activity of $O$. syriacum oil has been testified against $A$. ipsilon, this oil proved highly effective as an insecticide against other insects, such as Kaya et al. [58], who declared that 0 . syriacum oil produced the top toxicity at the lowest concentration $(30 \mu \mathrm{g} \mathrm{ml})$ compared to other oils, and it had the lowest value $\mathrm{LC}_{50}(11.2 \mu \mathrm{g} \mathrm{mL})$ against $C$. maculatus. This result is confirmed by the current study, where the $O$. syriacum oil scored the third point of toxicity $(65.3 \%)$ among the tested BOs against the $A$. ipsilon larvae. Despite; the differences in the tested insects, the similarity of the main ingredients in O. syriacum oil with previous studies helped realize the importance of using it as a powerful insecticide. These components (carvacrol, 1.8 cineole, menthol, camphor, terpene, and thymol) have sub-lethal deterrent actions on various insect species $[58,59]$.

Some previous reports have studied the toxic effects of the insecticides extracted from $A$. santolina, which have different efficacy against many insects when; its insecticidal activities differ according to the order of insects and used method. Therefore, some authors proved a highly toxic activity against Trogoderma granarium larvae [46]. On the contrary, the extract of $A$. santolina oil offered the lowest toxicity value at $\mathrm{LC}_{50}(4033 \mathrm{ppm})$ against Sitotroga cerealella larvae when; compared with nine plant extracts collected from North Sinai, Egypt [60]. The current study agreed with the previous findings that $A$. santolina oil was the least toxic among the other tested BOs under investigation.

Finally, although the above-mention plant oils have not been examined against $A$. ipsilon in the previous reports, the current results indicated variant degrees among the toxicity indices of the tested BOs, where the $A$. Judaica oil was the most toxic activity, followed by $M$. Iongifolia, $O$. syriacum, and $M$. hortensis, respectively. Moreover, $A$. santolina oil scored in the last point of the toxicity index against the $4^{\text {th }}$ instars of $A$. ipsilon.

\subsection{Toxicity Effects of the Tested BOs on the Nutritional Indices of $A$. ipsilon}

Data in Table 6 proved the effect of the tested BOs on the amount of ingested food, produced feces, weight gain, assimilated and metabolized food of the bollworm $4^{\text {th }}$ instar larvae, where the least amount was found in A. judaica at 143.42, $37.49, \quad 42.94, \quad 105.93$, and $62.99 \mathrm{mg}$, respectively. However, the highest amounts were detected in $A$. santolina at $351.25,72.72,176.79$, $278.53 \mathrm{mg}$, respectively, excluding Metabolized food. The results also indicated that there are significant differences between most of the tested BOs compared to the untreated sample, while no differences were found between $A$. santolina and the control, $M$. longifolia and $A$. judaica in produced feces; $M$. longifolia and $O$. syriacum, $M$. longifolia, $A$. santolina, and $M$. hortensis in metabolized food. 
The use of natural plant extracts in insect pest control programs has received much attention in recent years due to the environmental pollution, pest resistance, and adverse effects on the organisms resulting from the irregular use of pesticides. Food utilization efficiencies are useful for measuring the growth rate and development of the consumer [25] also; food quality of different host plants plays a crucial role in insect performance [61]. The least amount of assimilated food due to part of the ingested food was used by the larvae for transformation into biomass or energy for metabolism. Furthermore, the decreased amount of metabolized food could be owing to the highest amount of food used for growth and not metabolic energy. Shekari et al. [62] proved that the reduced food consumption; due to a stress of the chemical components of the botanical on the enzyme expression system to synthesize new and higher amounts of detoxification enzymes.

The data presented in Table 7 presented that the most toxic oils reduced larval weight without significant differences between $M$. longifolia and $O$. syriacum at 95.30 and $101.92 \mathrm{mg}$, respectively. These previously oils caused a notable decrease in RCR without differences between $O$. syriacum and $M$. hortensis at 0.567 and $0.644 \mathrm{mg} / \mathrm{mg} / \mathrm{d}$, respectively; meanwhile, the RMR showed a non-significant reduction in most tested BOs except $M$. longifolia. The RGR decrease was observed significantly between $A$. judaica and $O$. syriacum at 0.117 and 0.202 $\mathrm{mg} / \mathrm{mg} / \mathrm{d}$, respectively, while $A$. santolina and $M$. hortensis oil showed a non-significant decrease with control.

The current results showed that RCR was significant reduced with $A$. judaica and $M$. longifolia; this may be due to a low food intake or a toxic effect caused by the tested BOs. Furthermore, the RGR showed significant inhibition in $A$. judaica, M. longifolia, and $O$. syriacum indicated that these BOs were more effective and may act as an inhibitor. These results coincided with Senthil-Nathan [63] proved that Melia azedarach decreased the RCR and RGR of Cnaphalocrocis medinalis $4^{\text {th }}$ instar larvae (Lepidoptera: Pyralidae). Moreover, the methanol extract of $S$. marianum diminished the RGR of Pieris rapae larvae [64]. Furthermore, EISabrout et al. [52] detected that A. judaica, $O$. vulgare, Citrus lemone, Rosmarinuc officinalis, and Schinus molle reducing the RGR of $S$. littoralis larvae, reduced RGR may have come from severe damage in the cell surface of the midgut lumen. The RMR demonstrating the amount of food consumed in metabolism by larva per gram of body weight per day may help clear the metabolic capacity that can affect the growth. The obtained results exhibited that RMR nonsignificantly decreased in all BOs. That is maybe due to less food consumption or a toxic effect caused by the tested plant extracts, resulting in using the food for purposes other than growth, such as detoxification enzymes synthesis. These results concord with Carvalho et al. [65] cleared that RMR for treated $S$. frugiperda larvae with a trypsin inhibitor (isolated from $R$. communis leaves) non-significantly affected.

The current results in Table 8 showed that ECl values decreased when the larvae were exposed to the most toxic oils compared to the control at $28.89,29.94$, and $35.53 \%$ in the direction of $M$. longifolia, $A$. judaica, and $O$. syriacum, respectively, while those values increased for $M$. hortensis and A. santolina at 47.09 and $50.33 \%$, respectively. Likewise, the ECD values for the same previous oils were $36.23,40.54$, and $45.54 \%$ for the most toxic oils, 59.52 and $63.47 \%$ for the least efficient oils, respectively. Simultaneously, the outcomes didn't show significant differences between $M$. longifolia and $A$. judaica oils when used to reduce $\mathrm{ECl}$ and $E C D$. The AD revealed no significant reduction in all tested BOs. However, the MC recorded a highly significant increase in $M$. longifolia, $A$. judaica, and $O$. syriacum at $63.77,59.46$, and $54.46 \%$, respectively. Moreover, the antifeedant index indicated that A. judaica, $M$. longifolia, and $O$. syriacum were the highest feeding inhibitors at $66.45,52.54$, and $42.54 \%$, respectively.

ECD reflects metabolic efficiency and can be reduced by lowered the ECD or enhanced metabolic cost. As a response to decreased assimilation, more food is ingested, which increases RCR [24]. Both M. hortensis and $A$. santolina increased the food conversion efficiencies $\mathrm{ECl}$ and ECD. That may be attributed to the treated $4^{\text {th }}$ instars at $L_{50}$ values, which required large amounts of energy to deal with the toxicity of two tested BOs. These results concurred with $[64,66]$. However, both $\mathrm{ECl}$ and ECD exhibited a significant decrease for $A$. judaica and M. longifolia compared with control. These results agreed with Mordue (Luntz) \& Blackwell [67] stated that the reduction in ECl indicated that most food is converted into energy while less is converted to body tissue growth. ECD also diminished as the proportion of 
Table 6. Effect of the tested BOs at $\mathrm{LC}_{50}$ values on the amount of food consumption of the $4^{\text {th }}$ instars

\begin{tabular}{llllll}
\hline Treatments & \multicolumn{5}{c}{ Weights (mg \pm SD) } \\
\cline { 2 - 6 } & Ingested food & $\begin{array}{l}\text { Produced } \\
\text { feces }\end{array}$ & Weight gain & $\begin{array}{l}\text { Assimilated } \\
\text { food }\end{array}$ & $\begin{array}{l}\text { Metabolized } \\
\text { food }\end{array}$ \\
\hline M. longifolia & $202.91 \pm 14.42^{\mathrm{e}}$ & $41.08 \pm 3.77^{\mathrm{et}}$ & $58.63 \pm 5.34^{\mathrm{e}}$ & $161.83 \pm 11.15^{\mathrm{e}}$ & $103.2 \pm 8.21^{\mathrm{bc}}$ \\
A. judaica & $143.42 \pm 10.97^{\dagger}$ & $37.49 \pm 2.83^{\mathrm{c}}$ & $42.94 \pm 3.95^{\mathrm{f}}$ & $105.93 \pm 9.87^{\dagger}$ & $62.99 \pm 5.38^{\mathrm{d}}$ \\
M. hortensis & $304.87 \pm 22.56^{\mathrm{c}}$ & $63.65 \pm 7.22^{\mathrm{c}}$ & $143.57 \pm 12.64^{\mathrm{c}}$ & $241.22 \pm 17.23^{\mathrm{c}}$ & $97.65 \pm 7.13^{\mathrm{c}}$ \\
O. syriacum & $245.66 \pm 18.31^{\mathrm{d}}$ & $54.01 \pm 4.41^{\mathrm{d}}$ & $87.28 \pm 7.22^{\mathrm{d}}$ & $191.65 \pm 15.05^{\mathrm{d}}$ & $104.37 \pm 9.66^{\mathrm{b}}$ \\
A. santolina & $351.25 \pm 24.93^{\mathrm{b}}$ & $72.72 \pm 6.95^{\mathrm{a}}$ & $176.79 \pm 14.71^{\mathrm{b}}$ & $278.53 \pm 18.50^{\mathrm{b}}$ & $101.74 \pm 8.09^{\mathrm{c}}$ \\
Control & $427.53 \pm 31.66^{\mathrm{a}}$ & $70.81 \pm 7.1^{\mathrm{ab}}$ & $194.31 \pm 16.7^{\mathrm{a}}$ & $356.72 \pm 25.75^{\mathrm{a}}$ & $162.41 \pm 13.5^{\mathrm{a}}$ \\
F-value & $228.4^{\star *}$ & $70.03^{\star}$ & $320.1^{\star *}$ & $272.3^{\star *}$ & $126.1^{\star *}$ \\
\hline \multicolumn{4}{l}{ The values attached to the same letter within each column do not indicate statistical differences between them, }
\end{tabular}

$S D$ : standard Deviation, *: at $P \leq 0.05$, **: at $P \leq 0.01$

Table 7. Effect of the tested BOs at $\mathrm{LC}_{50}$ values on the consumption, metabolism, and growth rates of the $4^{\text {th }}$ instars

\begin{tabular}{lllll}
\hline Treatments & Larval wt. $(\mathbf{m g} \pm$ & \multicolumn{3}{c}{ Relative Rates (mg/mg/d ISD) } \\
\cline { 2 - 5 } & SD) & $\mathbf{R C R}$ & $\mathbf{R M R}$ & $\mathbf{R G R}$ \\
\hline M. longifolia & $95.30 \pm 7.25^{\mathrm{e}}$ & $0.481 \pm 0.08^{\mathrm{e}}$ & $0.244 \pm 0.05^{\mathrm{bc}}$ & $0.139 \pm 0.03^{\mathrm{cd}}$ \\
A. judaica & $81.83 \pm 6.74^{\mathrm{c}}$ & $0.389 \pm 0.07^{\dagger}$ & $0.171 \pm 0.04^{\mathrm{c}}$ & $0.117 \pm 0.02^{\mathrm{d}}$ \\
M. hortensis & $113.53 \pm 8.99^{\mathrm{c}}$ & $0.644 \pm 0.10^{\mathrm{cd}}$ & $0.206 \pm 0.06^{\mathrm{c}}$ & $0.303 \pm 0.08^{\mathrm{a}}$ \\
O. syriacum & $101.92 \pm 9.23^{\mathrm{de}}$ & $0.567 \pm 0.08^{\mathrm{d}}$ & $0.241 \pm 0.07^{\mathrm{c}}$ & $0.202 \pm 0.05^{\mathrm{bc}}$ \\
A. santolina & $135.01 \pm 12.26^{\mathrm{b}}$ & $0.665 \pm 0.10^{\mathrm{bc}}$ & $0.193 \pm 0.05^{\mathrm{c}}$ & $0.335 \pm 0.10^{\mathrm{a}}$ \\
Control & $148.49 \pm 13.01^{\mathrm{a}}$ & $0.825 \pm 0.14^{\mathrm{a}}$ & $0.313 \pm 0.09^{\mathrm{a}}$ & $0.375 \pm 0.13^{\mathrm{a}}$ \\
F-value & $64.79^{*}$ & $24.36^{*}$ & $6.56^{*}$ & $18.76^{*}$ \\
\hline
\end{tabular}

RCR: Relative consumption rate, RMR: Relative metabolic rate, RGR: Relative growth rate, the values attached to the same letter within each column do not indicate statistical differences between them, SD: standard Deviation, *: at $P \leq 0.05$, **: at $P \leq 0.01$

Table 8. Effect of the tested BOs at $\mathrm{LC}_{50}$ values on the food utilization, absorption, metabolic, and antifeedant activities of the $4^{\text {th }}$ instar larvae of $A$. ipsilon

\begin{tabular}{llllll}
\hline Treatments & \multicolumn{4}{c}{ Nutritional indices (\%) } & Anti-feeding \% \\
\cline { 2 - 5 } & $\mathrm{ECl}$ & $\mathrm{ECD}$ & AD & MC & \\
\hline M. longifolia & $28.89 \pm 1.76^{\dagger}$ & $36.23 \pm 2.90^{\mathrm{e}}$ & $79.75 \pm 8.15^{\mathrm{a}}$ & $63.77 \pm 4.85^{\mathrm{a}}$ & $52.54 \pm 3.94^{\mathrm{b}}$ \\
A. judaica & $29.94 \pm 2.02^{\mathrm{ef}}$ & $40.54 \pm 4.11^{\mathrm{de}}$ & $73.86 \pm 6.43^{\mathrm{a}}$ & $59.46 \pm 3.93^{\mathrm{b}}$ & $66.45 \pm 5.15^{\mathrm{a}}$ \\
M. hortensis & $47.09 \pm 3.66^{\mathrm{bc}}$ & $59.52 \pm 6.25^{\mathrm{a}}$ & $79.12 \pm 7.87^{\mathrm{a}}$ & $40.48 \pm 3.86^{\mathrm{e}}$ & $28.69 \pm 1.98^{\mathrm{d}}$ \\
O. syriacum & $35.53 \pm 2.55^{\mathrm{d}}$ & $45.54 \pm 3.96^{\mathrm{c}}$ & $78.01 \pm 6.99^{\mathrm{a}}$ & $54.46 \pm 5.05^{\mathrm{c}}$ & $42.54 \pm 3.65^{\mathrm{c}}$ \\
A. santolina & $50.33 \pm 4.75^{\mathrm{a}}$ & $63.47 \pm 5.38^{\mathrm{a}}$ & $79.30 \pm 8.24^{\mathrm{a}}$ & $36.53 \pm 4.17^{\mathrm{f}}$ & $17.84 \pm 1.56^{\mathrm{e}}$ \\
Control & $45.45 \pm 3.39^{\mathrm{c}}$ & $54.47 \pm 6.06^{\mathrm{b}}$ & $83.44 \pm 7.75^{\mathrm{a}}$ & $45.53 \pm 3.91^{\mathrm{d}}$ & $0.00 \pm 0.00^{\dagger}$ \\
F-value & $84.41^{*}$ & $48.68^{\star}$ & 1.65 & $63.31^{*}$ & $566.2^{\star *}$ \\
\hline
\end{tabular}

ECI: Efficiency of conversion of ingested food, ECD: Efficiency of conversion of digested food, AD: Approximate digestibility, MC: Metabolic cost, the values attached to the same letter within each column do not indicate statistical differences between them, SD: standard Deviation, *: at $P \leq 0.05$, **: at $P \leq 0.01$

digested food converted into energy increased; it exhibited a post-ingestion toxic effect, which can be considered secondary phagodeterrence responsible for the reduced $R C R, R G R$, and RMR. Some previous studies showed a reduction in $\mathrm{ECl}$ and $\mathrm{ECD}$ of some Lepidoptera larvae treated with various botanical extracts $[63,52]$.

AD denotes; the degree of food utilization depends on the digestibility of ingested food and the efficiency with which digested food (assimilated) converted into biomass [68]. It is based on variances between the weight of ingested food and feces, and it indicates the ability of an insect to absorb stored or metabolized food through the stomach wall. The achieved results showed a non-significant reduction of $A D$ in all tested $B O$ s, which may be due to the low percentage of excretion of consumed food by larvae because of the inhibitory effect of these tested BOs as compared 
to control. These results agreed with some stated results of inhibited $A D$ of various insects by some botanical extracts, for instance, Pieris rapae larvae treated with methanol extract of Silybium marianum [64], S. littoralis $4^{\text {th }}$ instar larvae treated with an alcohol extract of Conyza dioscoridis [66]. On the contrary, some results showed a rise in $A D$, such as Glyphodes pyloalis $4^{\text {th }}$ instar larvae treated with Thymus vulgaris and O. vulgare [69], Plutella xylustella $3^{\text {rd }}$ instar larvae treated with $O$. vulgare [70].

Antifeedant and growth activity inhibitors reduce pest damage by certain botanical products but without killing the pest. The present data manifested that the antifeedant index was highly significantly increased with $A$. judaica, $M$. longifolia, and $O$. syriacum, which proved that these BOs were the highest feeding inhibitors. These results coincided with Chennaiyan et al. [71] stated that Barleria longiflora leaves affect the $S$. litura larvae feeding behavior. Gvozdenac et al. [72] observed that Aesculus hippocastanum had a highly antifeeding activity against Lymantria dispar larvae. However, Ambrosia artemisiifolia, Daucus carota, and Elodea canadensis exhibited no antifeedant activity. Moreover, El-Sabrout et al. [52] showed that $A$. judaica, O. vulgare, C. lemone, $R$. officinalis, and $S$. molle had potent antifeedant effects on $S$. littoralis larvae.

\section{CONCLUSION}

Under our toxicity results, usage of $A$. judaica, $M$. longifolia, and $\mathrm{O}$. syriacum oils play a significant role in anti-nutritional activities, showing extensive deterrence potency and harmful impact on the food consumption, absorption, digestion, assimilation, and conversion, reflecting on growth and population of $A$. ipsilon larvae compared to $M$. hortensis and $A$. santolina oils. Accordingly, we would infer that these wild botanical extracts can be accepted as another successful choice in contrast to conventional synthetic pesticides and may assume a more influential part in the integrated pest control procedures against this insect later on.

\section{ACKNOWLEDGEMENTS}

The authors are grateful to Dr. Hussein A. Hussein, Botany Department, Faculty of Science, Zagazig University, Egypt, for helping in wild plant identification. We also thank Ibrahim $\mathrm{H}$. Ali, Sharqia STEM School, for assistance in insect rearing and plant collection. Furthermore, we extend our gratitude to the Bedouin communities from south Sinai for their guidance and hospitality.

\section{COMPETING INTERESTS}

Authors have declared that no competing interests exist.

\section{REFERENCES}

1. El-Shershaby MMA. Toxicity and biological effect of capparis leaves extracts to the black cutworm, Agrotis ipsilon (Hufn.). Egypt. Acad. J. biolog. Sci. (F. Toxicology \& Pest control). 2010;2:45-51. Available:https://doi.org/10.21608/EAJBSF .2010 .17462

2. Erasmus A, Van Rensburg JBJ, Vanden BJ. Effects of Bt maize on Agrotis segetum (Lepidoptera: Noctuidae): A pest of maize seedlings. Environ. Entomol. 2010;39:702706.

Available:https://doi.org/10.1603/EN09150

3. Shakur M, Ullah F, Naem M, Amin M, Saljoqi AUR, Zamin M. Effect of various insecticides for the control of potato cutworm (Agrotis ipsilon Huf., Noctuidae: Lepidoptera) at Kalam Swat. Sarhad J. Agric. 2007;23(2):423-426.

Corpus ID: 11891027

4. Capinera JL. Handbook of vegetable pests. 2nd ed. New York: Academic Press. 2020;729.

Available:https://doi.org/10.1016/C2017-001577-X

5. Osman MA, Mahmoud MF. Effects of bio rational insecticides on selected biological aspects of the Egyptian cotton leaf worm, Spodoptera littoralis (Boisd.) (Lepidoptera: Noctuidae). J. Plant Prot. Res. 2009;49:135-40.

Available:https://doi.org/10.2478/v10045009-0018-0

6. ElKholy RM, EIBamby MM, ElTawil MF, Abouamer WL. Effect of three plant extracts on some biological aspects of cotton leafworm, Spodoptera littoralis (Boisd.). Middle East J. Appl. Sci. 2014;4:243-251.

Accessed 18 January 2020.

Available:http://www.curresweb.com/mejas /mejas/2014/243-251.pdf

7. Rajendran S, Sriranjini V. Plant products as fumigant for stored-product insect control. J. Stored Prod. Res. 2008;44:126135. 
Available:https://doi.org/10.1016/j.jspr.200 7.08.003

8. Rahman $S$, Kumar $S$, Barman NC, Ferdous T. Plant extract as selective pesticide for integrated pest management. Biotechnol. Res. J. 2016;2:6-10.

Accessed 3 March 2020.

Available:http://biotechaccess.com/index.p $\mathrm{hp} / \mathrm{BR} /$ article/view/17

9. Emam NM. Histological and ultrastructural studies on the effect of Cleome droserifolia plant from Sinai on the liver and kidney tissues of rats. Egypt. J. Hosp. Med. 2010;39:229-248.

Accessed 25 February 2020.

Available:https://ejhm.journals.ekb.eg/articl e_16967.html

10. Choudhary DK, Sharma AK, Agarwal P, Varma A, Tuteja N. Volatiles and food security: role of volatiles in agroecosystems. Singapore: Springer; 2017. p.373. https://doi.org/10.1007/978-981-105553-9

11. Astani A, Reichling J, Schnitzler P. Comparative study on the antiviral activity of selected monotrepenes derived from essential oils. Phytother. Res. 2010;24: 673-679.

Available:https://doi.org/10.1002/ptr.2955

12. De Almeida RN, Agra Mde F, Maior FN, De Sousa DP. Essential oils and their constituents: anticonvulsant activity. Molecules 2011;16(3): 2726-2742.

Available:https://doi.org/10.3390/molecules 16032726

13. Jeyasankar A. Antifeedant, insecticidal and growth inhibitory activities of selected plant oils on black cutworm, Agrotis ipsilon (Hufnagel) (Lepidoptera: Noctuidae). Asian Pac. J. Trop. Dis. 2012;2:347-351.

Available:https://doi.org/10.1016/S22221808(12)60179-0

14. Elhosary RA, yacoub SS, Elhefny AS. Effect of some plant extracts on black cut worm Agrotis ipsilon (hufn). under laboratory conditions. Egypt. J. Agric. Res. 2013;91(2):495-506.

Accessed 11 April 2020.

Available:https://bu.edu.eg/staff/rashaalhos sary6-publications/15898

15. Sharaby A, Elnujiban A. Histological effects of some essential oils combination on different tissues of the black cut worm larvae Agrotis ipsilon (Hufn.). J. Innov. Pharm. Biol. Sci. 2016;3(4):6-11.

Accessed 11 April 2020.
Available:http://jipbs.com/VolumeArticles/A bstract/243_Abstract.pdf

16. Elbadawy MAE, Azab MM, El Din AMS, Radwan EMM. Toxicity of some plant oil nanoemulsions to Black Cutworm, Agrotis ipsilon Hufnagel (Lepidoptera: Noctuidae). Nanotechnol. Agric. Food Environ. 2019; 1:1-10.

Accessed 27 May 2020.

Available:https://nanoafe.ca/article/1/1/7

17. Khamis WM, Farag DA, Selim S. Efficacy of Artemisia judaica extract and certain insecticides against cotton leafworm, Spodoptera littoralis (Lepidoptera: Noctuidae). Egypt. Acad. J. Biolog. Sci. (F. Toxicology \& Pest control) 2018;10(2):3552.

Available:https://doi.org/10.21608/eajbsf.2 018.22726

18. Martinez AM, Aguado-Pedraza AJ, Viñuela $\mathrm{E}$, Rodríguez-Enríquez CL, Lobit $\mathrm{P}$, Gómez B, et al. Effects of ethanolic extracts of Argemone ochroleuca (Papaveraceae) on the food consumption and development of Spodoptera frugiperda (Lepidoptera: Noctuidae). Fla. Entomol. 2017;100(2):339-345.

Available:https://doi.org/10.1653/024.100.0 232

19. Louni M, Shakarami J, Negahban M. Insecticidal efficacy of nanoemulsion containing Mentha longifolia essential oil against Ephestia kuehniella (Lepidoptera: Pyralidae). J. Crop Prot. 2018;7(2):171182.

Accessed 30 December 2019.

Available:https://jcp.modares.ac.ir/article-316677-en.html

20. Adams RP. Identification of essential oil components by gas chromatography/ mass spectroscopy. Carol Stream: Allured Pub. Corporation; 1995.

Accessed 9 January 2020.

Available:https://www.cabdirect.org/cabdire ct/abstract/20083116584

21. Gesraha MA, Ebeid AR, Salem NY, Abdou WL. Comparative study on some biological indices of Agrotis ipsilon (Lepidoptera: Noctuidae) larvae treated with three control agents under laboratory conditions. Annu. Res. Rev. Biol. 2017;21(6): 1-8.

Available:https://doi.org/10.9734/ARRB/20 17/37895

22. Abbott WS. A method of computing the effectiveness of an insecticide. J. Econ. Entomol. 1925;18:265-267. 
Available:https://doi.org/10.1093/jee/18.2.2 $65 a$

23. Shaurub EH, Zohdy NZ, Abdel-Aal AE, Emara SA. Effect of chlorfluazuron and flufenoxuron on development and reproductive performance of the black cutworm, Agrotis ipsilon (Hufnagel) (Lepidoptera: Noctuidae). Invertebr. Reprod. Dev. 2018;62:27-34.

Available:https://doi.org/10.1080/07924259 .2017.1384407

24. Truzi CC, Holzhausen HG, Álvaro JC, De Laurentis VL, Vieira NF, Vacari AM, et al. Food consumption utilization, and life history parameters of Helicoverpa armigera (Lepidoptera: Noctuidae) reared on diets of varying protein level. J. Insect Sci. 2019;19:12.

Available:https://doi.org/10.1093/jisesa/iey 138

25. Scriber JM, Slansky FJr. The nutritional ecology of immature insects. Annu. Rev. Entomol. 1981;26:183-211.

Available:https://doi.org/10.1146/annurev.e n.26.010181.001151

26. Finney DJ. Probit analysis, 3rd ed. New York: Cambridge University Press; 1971.

Available:https://doi.org/10.1002/jps.26006 00940

27. Sokal RR, Rohlf FJ. Biometry: The principles and practice of statistics in biological research, 4th ed. New York: W. H. Freeman and Company; 2012.

Available:https://doi.org/10.2307/2343822

28. Dhifi W, Bellili S, Jazi S, Bahloul N, Mnif W. Essential oils' chemical characterization and investigation of some biological activities: A critical review. Medicines (Basel). 2016;3(4):25.

Available:https://doi.org/10.3390/medicines 3040025

29. Viuda-Martos M, El Gendy Ael-N, Sendra E, Fernández-López J, Abd El Razik KA, Omer EA, et al. Chemical composition and antioxidant and anti-Listeria activities of essential oils obtained from some Egyptian plants. J. Agric. Food Chem. 2010;58(16):9063-9070.

Available:https://doi.org/10.1021/jf101620c

30. Salama AM, Osman EA, EL-tantawy AA. Taxonomical studies on four mentha species grown in Egypt through morphoanatomical characters and scot genetic markers. Plant Arch. 2019;19(2);22732286.

Corpus ID: 209368316
31. Rasooli I, Rezaei MB. Bioactivity and chemical properties of essential oils from Zataria multiflora Boiss and Mentha Iongifolia (L.) Huds. J. Essent. Oil Res. 2002;14:141-146.

Available:https://doi.org/10.1080/10412905 .2002.9699800

32. Khani A, Asghari J. Insecticide activity of essential oils of Mentha longifolia, Pulicaria gnaphalodes and Achillea wilhelmsii against two stored product pests, the flour beetle, Tribolium castaneum, and the cowpea weevil, Callosobruchus maculatus. J. Insect Sci. 2012;12:73.

Available:https://doi.org/10.1673/031.012.7 301

33. Pavela R, Kaffková K, Kumšta $M$. Chemical composition and larvicidal activity of essential oils from different Mentha L. and Pulegium species against Culex quinquefasciatus Say (Diptera: Culicidae). Plant Protect. Sci. 2014;50:3642.

Available:https://doi.org/10.17221/48/2013PPS

34. Yildirim H, Bekircan C, Bektas E. Antifeedant effects of essential oil of Mentha longifolia subsp. Iongifolia L. HUDSON (Lamiaceae) on Subcoccinella vigintiquatuorpunctata L. (Coleoptera: Coccinellidae). Biol. Divers. Conserv. 2019;12(2):103-108.

Available:https://doi.org/10.5505/biodicon.2 019.27928

35. Monfared A, Nabid MR, Rustaiyan A. Composition of a carvone chemotype of Mentha longifolia (L.) Huds. from Iran. J. Essent. Oil Res. 2002;14:51-52.

Available:https://doi.org/10.1080/10412905 .2002.9699761

36. Zeinali H, Arzani A, Razmjoo K, Rezaee M. Evaluation of oil compositions of Iranian mints (Mentha ssp.). J. Essent. Oil Res. 2005;17:156-159.

Available:https://doi.org/10.1080/10412905 .2005 .9698863

37. Putievsky E, Ravid U, Dudai N, Katzir I, Carmeli D, Eshel A. Variations in the volatile oil Artemisia judaica L. Chemotypes related to phonological and environmental factors. Flav. Frag. J. 1992;7(5):253-257.

Available:https://doi.org/10.1002/ffj.273007 0504

38. Abdelgaleil SA, Abbassy MA, Belal AH, Abdel Rasoul MA. Bioactivity of two major constituents isolated from the essential oil 
of Artemisia judaica L. Bioresour. Technol. 2008;99(13):5947-5950.

Available:https://doi.org/10.1016/j.biortech. 2007.10.043

39. El-Massry KF, El-Ghorab AH, Farouk A. Antioxidant activity and volatile components of Egyptian Artemisia judaica L. Food Chem. 2002;79(3):331-336.

Available:https://doi.org/10.1016/s03088146(02)00164-4

40. Abu-Darwish MS, Cabral C, Gonçalves MJ, Cavaleiro C, Cruz MT, Zulfiqar A, et al. Chemical composition and biological activities of Artemisia judaica essential oil from southern desert of Jordan. J. Ethnopharmacol. 2016;191:161-168.

Available:https://doi.org/10.1016/j.jep.2016 .06 .023

41. Abbassy MA, Abdelgaleil SAM, Rabie RYA. Insecticidal and synergistic effects of Majorana hortensis essential oil and some of its major constituents. Entomol. Exp. Appl. 2009;131(3):225-232.

Available:https://doi.org/10.1111/j.15707458.2009.00854.x

42. Perry NB, Anderson RE, Brennan NJ, Douglas MH, Heaney AJ, McGrimpsey AJ, et al. Essential oil from Dalmation sage (Salvia officinalis L.), variations among individuals, plant parts, seasons and sites. J. Agric. Food Chem. 1999;47:2048-2054. Available:https://doi.org/10.1021/jf981170 $\mathrm{m}$

43. Figueredo G, Cabassu $\mathrm{P}$, Chalchat JC, Pasquier B. Studies of mediterranean oregano populations-V. Chemical composition of essential oils of oregano: Origanum syriacum L. var. Bevanii (Holmes) letswaart, $O$. syriacum $L$ var. Sinaicum (Boiss.) letswaart, and $O$. syracum $L$. var. syriacum from Lebanon and Israel. Flav. Frag. J. 2005;20:164-168. Available:https://doi.org/10.1002/ffj.1408

44. Lukas B, Schimiderer C, Franz C, Novak J. Composition of essential oil compounds from different Syrian populations of Origanum syriacum L. (Laminaceae). J. Agric. Food Chem. 2009;57:1362-1365.

Available:https://doi.org/10.1021/jf802963h

45. El-Shazly AM, Hafez SS, Wink M. Comparative study of the essential oils and extracts of Achillea fragrantissima (Forssk.) Sch. and Achillea santolina L. (Asteraceae) from Egypt. Pharmazie. 2004;59:226-230.

Available:https://pubmed.ncbi.nlm.nih.gov/ 15074599/
46. Nenaah GE. Chemical composition, insecticidal and repellence activities of essential oils of three achillea species against the Khapra beetle (Coleoptera: Dermestidae). J. Pest. Sci. 2014;87:273283.

Available:https://doi.org/10.1007/s10340013-0547-1

47. Bimbiraite K, Ragazinskiene O, Kornysova O. Comparison of the chemical composition of four yarrow (Achillea millefolium L.) morphotypes. Biologija 2008;54(3):208-212.

Available:https://doi.org/10.2478/v10054008-0046-0

48. Rahimmalek M, Tabatabaei BE, Etemadi N, Goli SA, Arzani A, Zeinali H. Essential oil variation among and within six Achillea species transferred from different ecological regions in Iran to the field conditions. Ind. Crops. Prod. 2009;29:348355.

Available:https://doi.org/10.1016/j.indcrop. 2008.07.001

49. Motavalizadehkakhky A, Ebrahimi Z, Emamiyan R, Mohamadian A, Abedi F. Chemical compositions of essential oils of different parts and extract of Achillea santolina L. from Iran. Asian J. Chem. 2013;25:6372-6376.

Available:https://doi.org/10.14233/ajchem. 2013.14647

50. Berramdane T, Gourine N, Bombarda I, Yousfi M. New chemotype of essential oil of Achillea santolina L. collected from different regions of Algeria. J. Food Meas. Charact. 2018;12: 1779-1786.

Available:https://doi.org/10.1007/s11694018-9793-5

51. Al-Sharook Z, Balan K, Jiang Y, Rembold $H$. Insect growth inhibitors from two tropical Meliaceae: Effects of crude seed extracts on mosquito larvae. J. Appl. Entomol. 1991;111:425-530.

Available:https://doi.org/10.1111/j.1439-

0418.1991.tb00344.x

52. El-Sabrout A, Zahran HE, Abdelgaleil S. Effects of essential oils on growth, feeding and food utilization of Spodoptera littoralis Larvae. J. Entomol. 2018; 15:36-46.

Available:https://doi.org/10.3923/je.2018.3 6.46

53. Saeidi Z, Babaahmadi $H$, Saeidi KA, Salehi $A$, Jouneghani RS, Amirshekari $H$, et al. Essential oil content and composition of Mentha longifolia (L.) Hudson grown wild in 
Iran. J. Med. Plant Res. 2012;29:45224525.

Accessed 15 April 2020.

Available:https://academicjournals.org/jour nal/JMPR/article-abstract/926516C27415

54. Tripathi AK, Prajapati V, Ahmad A, Aqqarwal KK, Khanuja SP. Piperitone oxide as toxic, repellent, and reproduction retardant toward malarial vector Anopheles stephensi (Diptera: Anophelinae). J. Med. Entomol. 2004;41: 691-698.

Available:https://doi.org/10.1603/00222585-41.4.691

55. Mohamed MIE, Abdelgaleil SAM. Chemical composition and insecticidal potential of oils from Egyptian plants against Sitophilus oryzae (L.) (Coleop-tera: Curculionidae) and Tribolium castaneum (Herbst) (Coleoptera: Tenebrionidae). Appl. Entomol. Zool. 2008;43:599-607. Available:https://doi.org/10.1303/aez.2008. 599

56. Koliopoulos G, Pitarokili D, Kioulos E, Michaelakis A, Tzakou O. Chemical composition and larvicidal evaluation of mentha, salvia and melissa essential oils against the west nile virus mosquito Culex pipiens. Parasitol. Res. 2010;107(2):327335.

Available:https://doi.org/10.1007/s00436010-1865-3

57. Isman MB. Plant essential oils for pest and disease management. Crop Prot. 2000;19: 603-608.

Available:https://doi.org/10.1016/S02612194(00)00079-X

58. Kaya K, Sertkaya E, Üremiş I, Soylu S. Determination of chemical composition and fumigant insecticidal activities of essential oils of some medicinal plants against the adults of cowpea weevil, Callosobruchus maculatus. KSÜ Tarım ve Doğa Derg. 2018;21(5):708-714.

Available:https://doi.org/10.18016/ksudobil. 386176

59. Park CG, Shin E, Kim J. Insecticidal activities of essential oils, Gaultheria fragrantissima and Illicium verum, their components and analogs against Callosobruchus chinensis adults. J. AsiaPas. Entomol. 2016;19:269-273.

Available:https://doi.org/10.1016/j.aspen.2 016.03.001

60. Fathy MO, El-Araby RE, Ahmed YM. Toxicological studies on some natural plants in north sinai against sitotroga cerealella larvae. SINAI J. Appl. Sci. 2017;6(2):193-202.

Available:https://doi.org/10.21608/SINJAS. 2017.78785

61. Slansky F. Insect nutritional ecology as a basis for studying host plant resistance. Fla. Entomol. 1990;73:359-378.

Available:https://doi.org/10.2307/3495455

62. Shekari M, Sendi JJ, Etebari K, Zibaee A, Shadparvar A. Effects of Artemisia annua L. (Asteracea) on nutritional physiology and enzyme activities of elm leaf beetle, Xanthogaleruca luteola Mull. (Coleoptera: Chrysomellidae). Pestic. Biochem. Physiol. 2008;91:66-74.

Available:https://doi.org/10.1016/j.pestbp.2 008.01 .003

63. Senthil-Nathan S. Effects of Melia azedarach on nutritional physiology and enzyme activities of the rice leafolder Cnaphalocrocis medinalis (Guenée) (Lepidoptera: Pyralidae). Pestic. Biochem. Physiol. 2006;84:98-108.

Available:https://doi.org/10.1016/j.pestbp.2 005.05 .006

64. Hasheminia SM, Sendim JJ, Jahromi KT, Moharramipour S. Effect of milk thistle, Silybium marianum, extract on toxicity, development, nutrition, and enzyme activities of the small white butterfly, Pieris rapae. J. Insect Sci. 2013;13:146.

Available:http://doi.org/10.1673/031.013.14 601

65. Carvalho GA, Santos CD, Alves DS, Carvalho GA, Cardoso MG, Haro MM. Toxic effects of Ricinus communis nonprotein trypsin inhibitor on Spodoptera frugiperda (J.E. Smith) (Lepidoptera: Noctuidae). Afr. J. Biotechnol. 2015;14(42):2928-2936.

Available:https://doi.org/10.5897/AJB2015. 14590

66. Ebeid AR, Sammour EA, Zohdy NZM. Role of challenger pesticide and plant extracts on some physiological parameters of the cotton leafworm, Spodoptera littoralis (Boisd.). Arch. Phytopathol. Pflanzenschutz 2015;48(5):385-392.

Available:https://doi.org/10.1080/03235408 .2014.893631

67. Mordue (Luntz) AJ, Blackwell A. Azadirachtin: An update. J. Insect Physiol. 1993;39(11):903-924.

Available:https://doi.org/10.1016/00221910(93)90001-8

68. Batista Pereira GL, Petacci F, Fernandes BJ, Correa AG, Vieira PC, Fatima da Silva 
$\mathrm{M}$, et al. Biological activity of astilbin from Dimorphandra mollis against Anticarsia gemmatalis and Spodoptera frugiperda. Pest Manag. Sci. 2002;58(5):503-507.

Available:https://doi.org/10.1002/ps.478

69. Yazdani E, Sendi JJ, Hajizadeh J. Effect of Thymus vulgaris $\mathrm{L}$. and Origanum vulgare L. essential oils on toxicity, food consumption, and biochemical properties of lesser mulberry pyralid Glyphodes pyloalis Walker (Lepidoptera: Pyralidae). J. Plant Prot. Res. 2014;54:53-61.

Available:https://doi.org/10.2478/jppr-20140008

70. Nasr M, Sendi JJ, Moharramipour S, Zibaee A. Evaluation of Origanum vulgare L. essential oil as a source of toxicant and an inhibitor of physiological parameters in diamondback moth, Plutella xylustella L. (Lepidoptera: Pyralidae). J. Saudi Soc. Agri. Sci. 2017;16(2):184-190.
Available:https://doi.org/10.1016/j.jssas.20 15.06.002

71. Chennaiyan V, Sivakami R, Jeyasankar A. Evaluating ecofriendly botanicals of Barleria longiflora Linn. F. (Acanthaceae) against armyworm Spodoptera litura Fab. and cotton bollworm Helicoverpa armigera Hübner (Lepidoptera: Noctuidae). Annu. Res. Rev. Biol. 2016;10(3): 1-9.

Available:https://doi.org/10.9734/ARRB/20 16/23691

72. Gvozdenac S, Inđić D, Vuković $S$, Grahovac M, Tanasković S. Antifeeding activity of several plant extracts against Lymantria dispar L. (Lepidoptera: Lymantriidae) larvae. Pestic. Phytomed. 2012;27(4):305-311.

Available:https://doi.org/10.2298/PIF12043 05G

(c) 2021 Nasr et al.; This is an Open Access article distributed under the terms of the Creative Commons Attribution License (http://creativecommons.org/licenses/by/4.0), which permits unrestricted use, distribution, and reproduction in any medium, provided the original work is properly cited.

Peer-review history:

The peer review history for this paper can be accessed here: http://www.sdiarticle4.com/review-history/66558 